\title{
Foliar Application of Fungicides Registered Against Late Blight Influences Main Potato Tuber Diseases and Key Quantitative Characteristics of Tubers
}

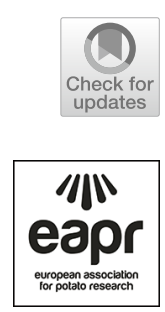

\author{
Petr Sedlák ${ }^{1}$ (D) . Vladimíra Sedláková ${ }^{1} \cdot$ Petr Doležal $^{2} \cdot$ Petra Baštová $^{2}$. \\ Jakub Vašek ${ }^{1}$ - Ervín Hausvater ${ }^{2}$
}

Received: 20 December 2020 / Accepted: 18 June 2021 / Published online: 7 January 2022

(c) The Author(s) 2022

\begin{abstract}
Adequate integrated management of potato leaf diseases can have an influence on pathogens which are challenging to control and cause main potato tuber diseases. Deriving from this hypothesis, an experiment was designed to evaluate the efficacy of foliar application of twelve fungicides on late blight in tubers, common scab, black scurf and silver scurf. In the period of 2013 to 2017, the fungicides were equally applied six times in registered doses during the growing seasons. Eight tuber disease indicators and eight yield characteristics were then evaluated in harvested tuber samples. Significant differences were found among the fungicides used. In comparison to the negative control (n. c.), the application of Infinito, Ranman Top and Revus Top reduced the quantity of tubers infected by late blight by $72 \%$ on average. The incidence of common scab increased by $65 \%$ of n. c. under the effect of copper oxychloride, while an average reduction by $19 \%$ of n. c. was observed with the use of Acrobat MZ WG, Curzate Gold and Consento. The occurrence of silver scurf was significantly enhanced by Curzate Gold and Consento (105\% of n. c.), while it was suppressed by Revus Top and Revus (85\% of n. c.). All fungicides were ineffective on black scurf yet had a positive influence on the potato yield and quality, with the choice of fungicide having a great impact on the quality of tubers. The application of any safe fungicide is important, especially in years similar to 2015, which was the most devastating recent year for potato production in terms of structural changes in yield of tubers.
\end{abstract}

Keywords Antifungal protection - Common scab - Diseases of potato tubers - Late blight $\cdot$ Potato production $\cdot$ Silver scurf

Petr Sedlák

sedlak@af.czu.cz

Extended author information available on the last page of the article 


\section{Introduction}

Common scab (Streptomyces scabiei Thaxter), silver scurf (Helminthosporium solani Durieu and Mont.) and black scurf (Rhizoctonia solani Khün (teleomorph Thanatephorus cucumeris (A. B. Frank) Donk) are soil-borne diseases of potato. They have primarily a negative influence on the market quality of tubers (Errampalli et al. 2001) together with late blight (Phytophthora infestans (Mont.) de Bary), which is the most important pathogen of potatoes worldwide (Haas et al. 2009) and causes annual losses exceeding one billion EUR in the European Union and several billion US dollars worldwide (Haverkort et al. 2008). Several complex studies on the biology of pathogens and the influence of environmental factors on soil-borne diseases have previously been published (e.g. Carling et al. 1989; Rotem 1994; Firman and Allen 1995; Loria 2001; Meyer et al. 2006; Rasocha et al. 2008; Miller et al. 2015). Although the foliar diseases can be controlled relatively effectively by contact fungicides (e.g., mancozeb, copper oxychloride), the protection against soil pathogens is more difficult. Indirect agronomical measures, including planting of visually healthy seed tubers and standard rotation of crops, are generally insufficient. Furthermore, the direct chemical/biological management of these pathogens is technically difficult or even impossible (Rasocha et al. 2008). Wilson et al. (1999) reported effectiveness of seed dressing treatments on the severity of common scab using fluazinam, mancozeb and other active ingredients. Similarly, Atkinson et al. (2011) verified that seed potato treatments by mancozeb combined with fludioxonil and in-furrow application of azoxystrobin are measures that significantly reduce symptoms of Rhizoctonia stem canker and black scurf. However, more reliable strategies for direct protection than the two mentioned above are currently unavailable.

Our previous study aimed at the evaluation of the efficacy of standard foliar fungicide sequences on the late blight indicated the effective reduction of soilborne diseases by certain active ingredients (Sedláková et al. 2011). Using current registered fungicides verified as 'efficient against the soil-borne diseases' is constructive when considering current EU policy in agriculture. It supports complex strategies of integrated crop protection (Barzman et al. 2015) and functions towards the reduction of reliance on the pesticides (Lamichhane et al. 2016). However, this strategy is more open to restrictions of commonly used/overused pesticides representing potential risks for the health and environment compared to registrations of new safer active ingredients. This has been noticed in recently restricted mancozeb, widely used in many different crops (Meyer et al. 2006), including potato (Gullino et al. 2010), in either single ingredient formulations (Dithane DG Neotec) or combined with other systemic ingredients (Acrobat MZ WG, Curzate Gold, Emendo M, Ridomil Gold MZ Pepite). Similarly, copperbased fungicides (e.g. Kuprikol 50) essential for organic farming (Finckh et al. 2006) and globally overused (Lamichhane et al. 2018) could be endangered for potential toxicity of copper accumulated in produce (Ferreira et al. 2014) or topsoil (Zhu et al. 2012). They also reduce the activity of soil microbiota (Deng et al. 2009). In advancing technologies used for potato production, fungicide protection 
is inevitable and a critical consequence of necessary late blight management. This causes an inherent difficulty to restrict active ingredients for potato growth. Permanent needs of optimization of direct disease/pest management, more detailed evaluations of risks/benefits of current ingredients and searching for new safer active ingredients are therefore required as a solution.

The principal aim of this study, motivated by our previous research as well as the general situation in the field of chemical disease management, was to verify the hypothesis that regular foliar application of available fungicides influences progress of soil-borne diseases and impacts the final quantity and quality of tubers. This paper presents and discusses the main significant findings of this study.

\section{Material and Methods}

\section{Establishment of Field Trials}

The field trials were established at the research station of the Potato Research Institute in Valečov (460 masl, Vysočina Region, Czech Republic) in a sequence of five experimental seasons (from 2013 to 2017). The soil ranged from medium to heavy with a loamy to sand-loamy topsoil of pH value 5.8 (2013), 5.9 (2014), 5.6 (2015), 5.5 (2016) and 5.5 (2017). Experimental plots were chosen in order to keep a homogeneity in both soil quality and risk of occurrence of subject pathogens. None of the chosen fields was associated with any extraordinary occurrence of diseases. Potatoes were grown in 4-year crop rotation after spring barley.

The experiment comprised thirteen variants (Table 1) in four completely randomized replicates. Each experimental plot $\left(25 \mathrm{~m}^{2}\right)$ comprised one hundred tubers, of medium-early Austrian yellow-fleshed potato cultivar Ditta, planted evenly into four rows. The cultivar is known to have medium resistance to late blight of foliage and high resistance to late blight of tubers, high resistance to Rhizoctonia canker and medium resistance to common scab (European Cultivated Potato Database). The resistance to silver scurf has not been officially published, but on the basis of our long-term field evaluations, this has been assumed to be medium resistance for this study. Annually, certified seed tubers of grade A with absence or only sporadic symptoms of the diseases were planted. The trial was subjected solely to a natural infection of pathogens. The fungicide treatments were initiated as preventive measures after crop canopy closure (third week of June) and performed in six consecutive applications at 10-day intervals during the growing period using electric knapsack sprayers (Vermorel 2000 Berthoud, Villefranche, France).

\section{Evaluation of the Experiment}

The foliar diseases (late blight in a complex with early blight (Alternaria solani)) were monitored from the beginning of July after reaching the critical value of late blight negative prognosis (150), as determined by the regression of relative air humidity and daily temperatures (Ullrich and Schrödter 1966). Dates of the 


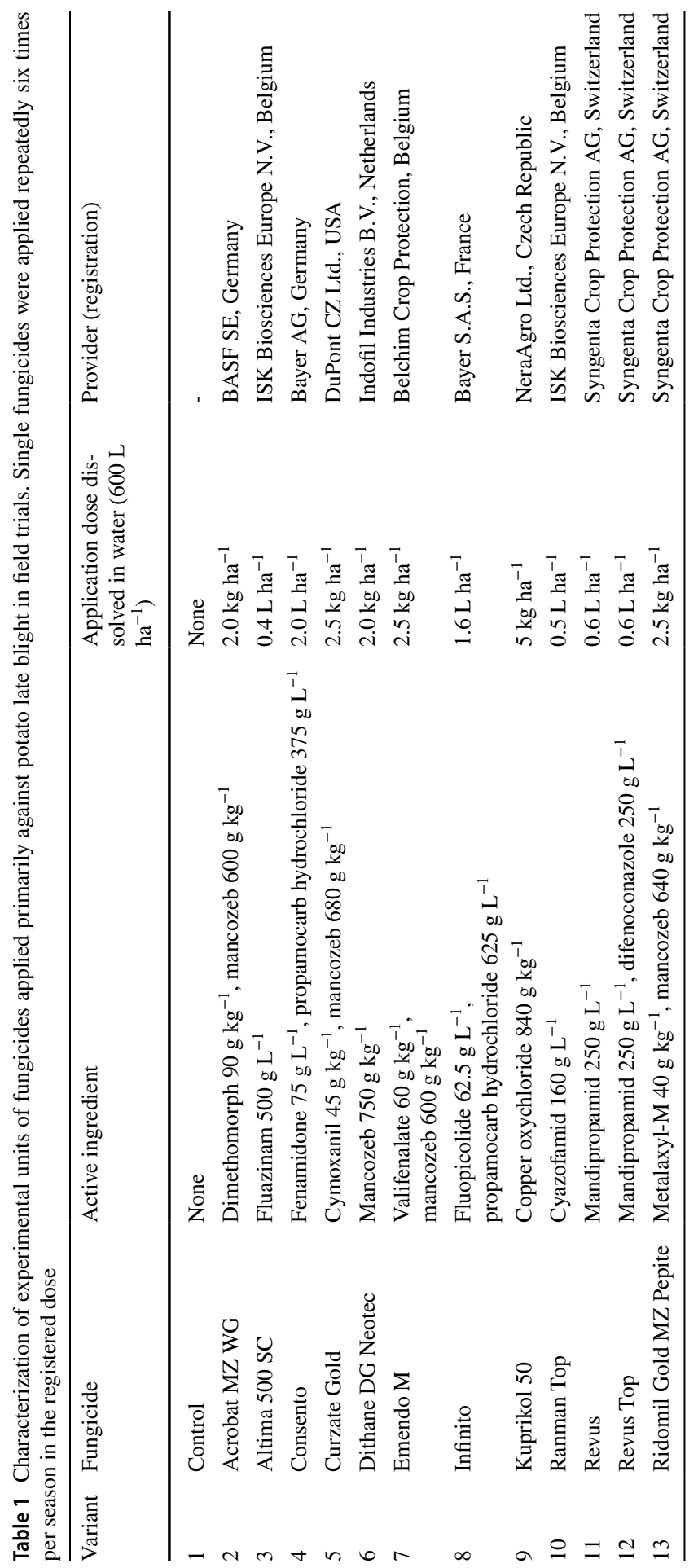


Table 2 General characteristics of foliar diseases within the experimental period. In the extreme year 2015, no relevant data were recorded for any disease

\begin{tabular}{lllll}
\hline Year & $\begin{array}{l}\text { Late blight: infection pres- } \\
\text { sure and date of beginning }\end{array}$ & $\begin{array}{l}\text { Early blight: infection pres- } \\
\text { sure and date of beginning }\end{array}$ & $\begin{array}{l}\text { Late blight: } \\
\text { duration (days) }\end{array}$ & 100\% foliar damage \\
\hline 2013 & Medium $\left(12^{\text {th }} \mathrm{Jul}\right)$ & Low $\left(4^{\text {th }} \mathrm{Aug}\right)$ & 74 & $24^{\text {th }}$ Sep \\
2014 & Medium $\left(30^{\text {th }} \mathrm{Jul}\right)$ & High $\left(8^{\text {th }} \mathrm{Aug}\right)$ & 37 & $4^{\text {th }} \mathrm{Sep}$ \\
2015 & Not observed & Not observed & - & - \\
2016 & Medium $\left(18^{\text {th }} \mathrm{Jul}\right)$ & Medium $\left(24^{\text {th }} \mathrm{Jul}\right)$ & 43 & $29^{\text {th }}$ Aug \\
2017 & Low $\left(1^{\text {st }} \mathrm{Aug}\right)$ & Medium $\left(15^{\text {th }} \mathrm{Jul}\right)$ & 58 & $27^{\text {th }}$ Sep \\
\hline
\end{tabular}

observations of first symptoms are presented in Table 2. The leaf disease progress was evaluated weekly as a percentage of foliar damage. The results for individual variants were converted to AUDPC (area under the disease progress curve) values according to Jeger and Viljanen-Rollinson (2001). The AUDPC values were transformed to rAUDPC (relative) on the basis of the untreated variant $(100 \%)$.

At the end of vegetative growth, all tubers from two middle rows $\left(12.5 \mathrm{~m}^{2}\right)$ of each experimental plot were harvested, weighed and sorted. In the tuber samples, the following parameters were evaluated: the total number and weight of tubers; the hectare yield; the number and weight of tubers in size range under $3.5 \mathrm{~cm}$, between 3.5 and $6.5 \mathrm{~cm}$ and over $6.5 \mathrm{~cm}$; and the number and weight of tubers infected by potato late blight. Subsequently, one hundred randomly selected middle-sized tubers per sample were evaluated for incidence (percentage of infected tubers) and severity of common scab, black scurf and silver scurf. The severity was estimated using a nine-point scale $(1=$ tuber without symptoms, $9=$ symptoms fully cover the tuber), created by Wenzl and Demel (1967). The data were statistically processed using software Statistica 12 (StatSoft, USA). The effects of the primary factors (fungicide and year) and their interactions on the mentioned characteristics were tested using the two-factor analysis of variance (ANOVA). Significant differences between mean values were detected by Tukey's post hoc test at significance level $\alpha=0.05$. Dataset collected in 2015 was found to be extremely affected by drought, and due to the consequent significant heterogeneity in variances of primary factors, it was removed from evaluation of long-term effects of fungicides. Finally, the regression and correlation analysis across all characteristics was performed using contingency tables.

\section{Results}

The ANOVA (general results presented in Tables 3 and 5) detected significant differences between the years within the experimental period. However, the extreme weather conditions for 2015 had such an anomalous negative influence on the evaluated characteristics that data from that year has been removed when considering statistical analysis of long-term effects of fungicides. Although the differences between fungicide variants in the years individually were insignificant, a processing of data across the 4 successful years uncovered significant 
Table 3 The two-way ANOVA table for diseases on tubers

\begin{tabular}{|c|c|c|c|c|c|}
\hline Characteristics/factor & Df & Sum sq & Mean sq & $F$-value & $P$-value \\
\hline \multicolumn{6}{|c|}{ Number of tubers infected by late blight } \\
\hline Fungicide & 12 & 7422.23 & 618.52 & 5.24 & 0.000 \\
\hline Year & 3 & $44,557.48$ & $14,852.49$ & 125.73 & 0.000 \\
\hline Fungicide*Year & 36 & $19,087.27$ & 530.20 & 4.49 & 0.000 \\
\hline Residuals & 156 & $18,429.00$ & 118.13 & & \\
\hline \multicolumn{6}{|c|}{ Tubers infected by late blight $[\mathrm{kg}]$} \\
\hline Fungicide & 12 & 48.20 & 4.02 & 3.46 & 0.000 \\
\hline Year & 3 & 248.44 & 82.81 & 71.28 & 0.000 \\
\hline Fungicide*Year & 36 & 133.04 & 3.70 & 3.18 & 0.000 \\
\hline Residuals & 156 & 181.24 & 1.16 & & \\
\hline \multicolumn{6}{|l|}{ Common scab severity } \\
\hline Fungicide & 12 & 1.55 & 0.13 & 3.61 & 0.000 \\
\hline Year & 3 & 6.45 & 2.15 & 60.10 & 0.000 \\
\hline Fungicide*Year & 36 & 1.83 & 0.05 & 1.42 & 0.076 \\
\hline Residuals & 156 & 5.58 & 0.04 & & \\
\hline \multicolumn{6}{|c|}{ Common scab incidence [\%] } \\
\hline Fungicide & 12 & 8934.30 & 744.52 & 4.30 & 0.000 \\
\hline Year & 3 & $24,680.25$ & 8226.75 & 47.49 & 0.000 \\
\hline Fungicide*Year & 36 & 8728.82 & 242.47 & 1.40 & 0.084 \\
\hline Residuals & 156 & $27,022.75$ & 173.22 & & \\
\hline \multicolumn{6}{|l|}{ Black scurf severity } \\
\hline Fungicide & 12 & 0.59 & 0.05 & 0.65 & 0.797 \\
\hline Year & 3 & 6.67 & 2.22 & 29.25 & 0.000 \\
\hline Fungicide* Year & 36 & 2.13 & 0.06 & 0.78 & 0.810 \\
\hline Residuals & 156 & 11.86 & 0.08 & & \\
\hline \multicolumn{6}{|c|}{ Black scurf incidence [\%] } \\
\hline Fungicide & 12 & 1324.73 & 110.39 & 0.73 & 0.718 \\
\hline Year & 3 & $14,708.32$ & 4902.77 & 32.52 & 0.000 \\
\hline Fungicide*Year & 36 & 4919.62 & 136.66 & 0.91 & 0.624 \\
\hline Residuals & 156 & $23,521.25$ & 150.78 & & \\
\hline \multicolumn{6}{|l|}{ Silver scurf severity } \\
\hline Fungicide & 12 & 6.70 & 0.56 & 3.09 & 0.001 \\
\hline Year & 3 & 928.81 & 309.60 & 1717.13 & 0.000 \\
\hline Fungicide*Year & 36 & 7.83 & 0.22 & 1.21 & 0.217 \\
\hline Residuals & 156 & 28.13 & 0.18 & & \\
\hline \multicolumn{6}{|c|}{ Silver scurf incidence [\%] } \\
\hline Fungicide & 12 & 1640.70 & 136.73 & 1.82 & 0.049 \\
\hline Year & 3 & $212,133.75$ & $70,711.25$ & 940.75 & 0.000 \\
\hline Fungicide*Year & 36 & 4178.57 & 116.07 & 1.54 & 0.037 \\
\hline Residuals & 156 & $11,725.75$ & 75.17 & & \\
\hline \multicolumn{6}{|l|}{ rAUDPC } \\
\hline Fungicide & 12 & 6.97 & 0.58 & 54.30 & 0.000 \\
\hline
\end{tabular}


Table 3 (continued)

\begin{tabular}{llllll}
\hline Characteristics/factor & Df & Sum sq & Mean sq & $F$-value & $P$-value \\
\hline Year & 3 & 2.08 & 0.69 & 64.88 & 0.000 \\
Fungicide*Year & 36 & 1.33 & 0.04 & 3.47 & 0.000 \\
Residuals & 156 & 1.67 & 0.01 & & \\
\hline
\end{tabular}

differences. These differences were not generally found between fungicides and control variant, but were found when comparing two or more fungicides. The results presented and discussed below were summarized in Tables 4 and 6 using homogeneous groups based on significant differences $(P<0.05)$.

\section{Late Blight in Foliage and Tubers}

The experimental years differed in the disease progress as evaluated by AUDPC (Fig. 1). The values of rAUDPC among individual years differed significantly $(P<0.05)$ and were sorted to four homogeneous groups: $2015^{\mathrm{a}}(0), 2016^{\mathrm{b}}$ $(28.18 \%), 2013^{\mathrm{c}}(46.42 \%)$ and $2014^{\mathrm{c}}(44.69 \%)$, and $2017^{\mathrm{d}}(55.99 \%)$. This corresponded with the data presented in Table 2 and Fig. 2. The rAUDPC was effectively reduced by the majority of fungicides apart from Infinito, Kuprikol 50, Ranman Top and Revus. The economically impactful occurrence of late blight in tubers was observed only in 2013, when it caused a significant loss of tubers in the equivalence of 2.2 tonnes per hectare. This was because of weather conditions which had supported disease progress and infection of tubers by zoospores. The same factor prolonged the growth of tubers by 20 days, which resulted in a greater harvest (Table 6). Evaluating the general correlations, statistically significant dependency of the late blight in tubers on the disease progress in foliage was not present.

Significant differences were found in the efficacy of fungicides on late blight in tubers (Table 4). The quantity of infected tubers increased under effect of Dithane DG Neotec, equalling to a 1.6 tonnes loss. Conversely, the tubers were very well protected by Infinito, Ranman Top and Revus Top. A very low number and weight of infected tubers in these treatments caused an estimated average loss equivalent to $165 \mathrm{~kg}$ per hectare. Compared with Dithane DG Neotec, for fungicides Altima $500 \mathrm{SC}$, Consento and Revus, the number of infected tubers significantly decreased but not the weight. Significant interaction between year 2013 and the efficacy of all five mancozeb-based fungicides was found for the weight of infected tubers per sample. Considering the number of infected tubers, the inefficacy during 2013 was clearly visible in all mancozeb- and copper-based fungicides. This confirms that these fungicides are not able to protect tubers against late blight in the years with optimal epidemiological condition. 


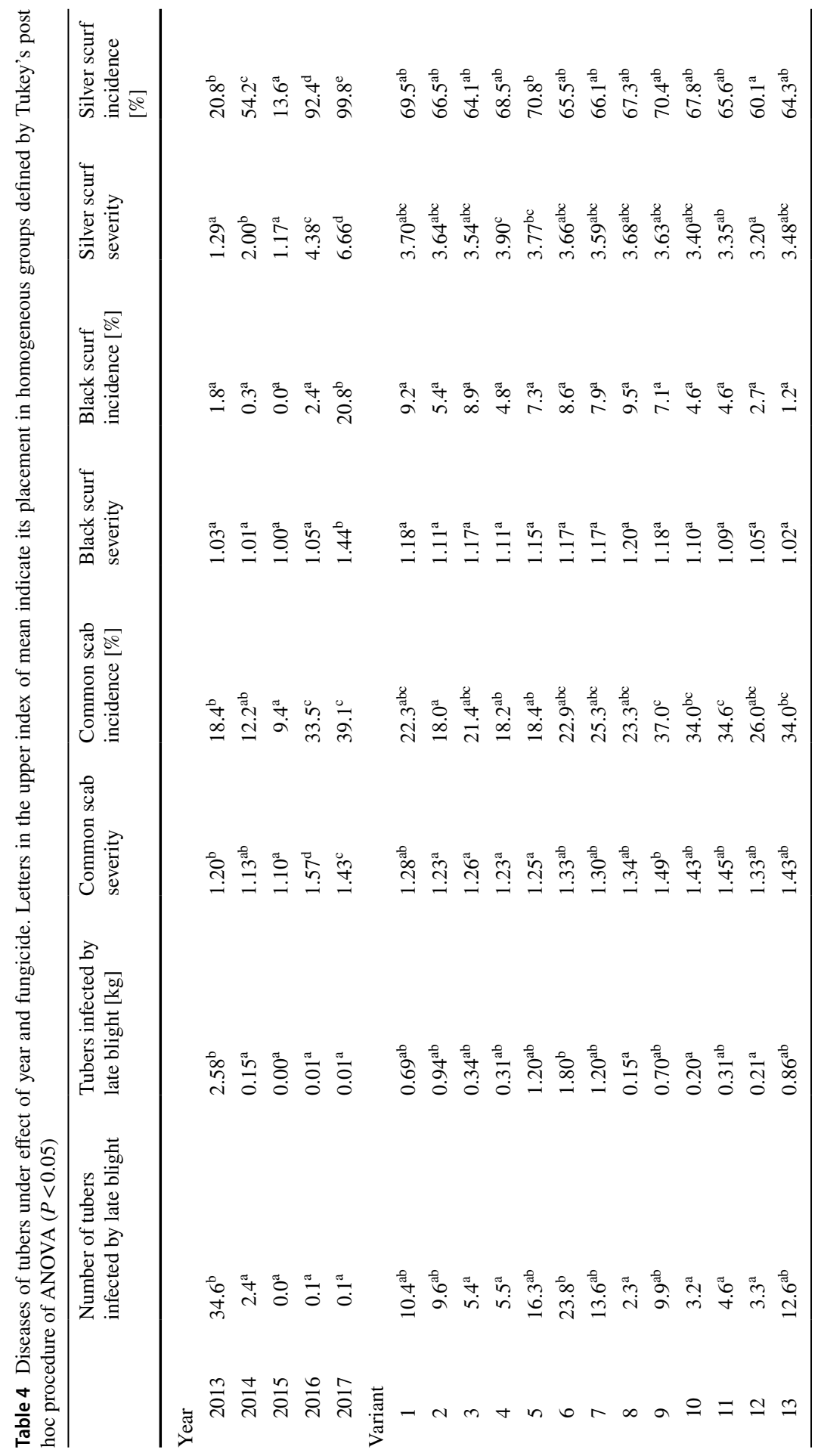




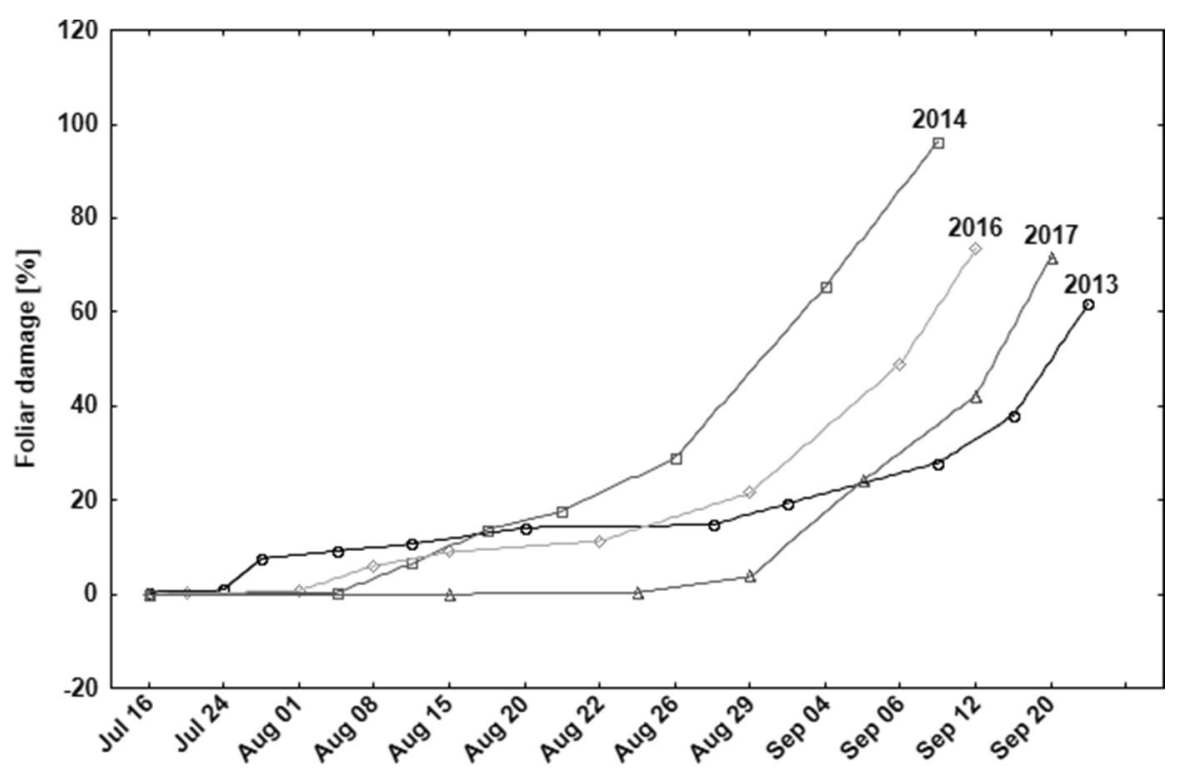

Date of evaluation

Fig. 1 The progress of leaf diseases in untreated plots. While in 2017 the weather conditions only delayed the leaf diseases complex, in 2015, no valuable data were collected

Mean rAUDPC

Vertical bars denote 0.95 confidence intervals

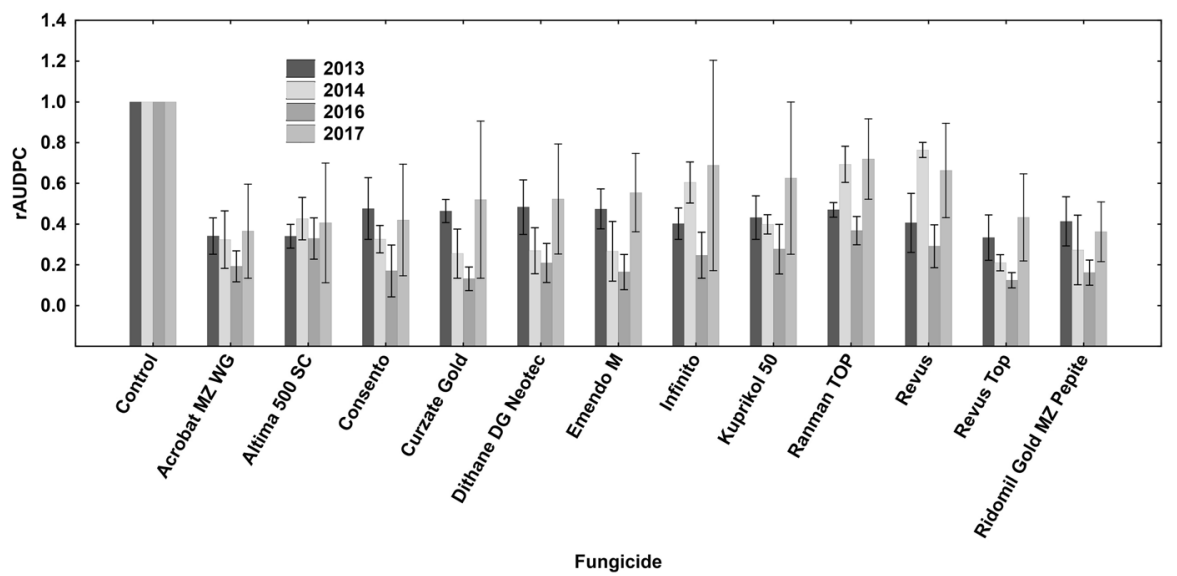

Fig. 2 rAUDPC values of single fungicide variants in 2013, 2014, 2016 and 2017. The values reflect only the injury of potato foliage caused by the complex of leaf diseases. Vertical bars denote 0.95 confidence intervals $(+/-2 \mathrm{SD})$ 


\section{Soil-Borne Diseases}

The incidence and severity of soil-borne diseases varied with the fungicide treatment and the year (Tables 3 and 4). The black scurf significantly varied only from year to year, with the highest incidence (20.8\% of tubers) being observed in 2017 , compared to $2.4 \%$ in other years.

Silver scurf gradually increased and reached its peak in 2017. The application of Revus Top significantly mitigated incidence and severity of the disease in comparison to Curzate Gold and Consento, respectively. Compared to control variant, the incidence and severity under effect of Revus Top were lower by $14 \%$. Curzate Gold worsened both by $2 \%$ and Consento worsened solely the severity by $5 \%$. These results are significant, particularly because they imply how the variation of the disease symptoms was influenced by frequent significant interactions between years and fungicide treatments.

Generally, the incidence and severity of common scab were very low in 2013 and 2014 , reaching a maximum in 2017. When compared to the control variant, the use of Kuprikol 50, Revus, Ranman Top and Ridomil Gold MZ worsened the incidence by $13 \%$ and the severity by $56 \%$ on average. The incidence was lower by approximately 20\% using variants Acrobat MZ WG, Consento and Curzate Gold. Fungicides Dithane DG Neotec, Infinito, Kuprikol 50 and Revus also presented strong risk of the disease corresponding to the years 2016 and 2017, when the conditions for disease progress were the most optimal. Significant differences of incidence and severity between particular fungicides are visible in Table 4.

\section{Yield Characteristics}

The yield of tubers per hectare was the least variable tuber characteristic across the years. Other characteristics also varied and were influenced by interactions between year and fungicide treatment. The results summarized in Tables 5 and 6 show that fungicides had a generally positive effect, primarily on the total yield of tubers per hectare, since the harvest from untreated control remained significantly lower, particularly in the years with normal weather conditions, where the loss of marketable tubers (above $3.5 \mathrm{~cm}$ ) in the control variant was approximately $18.5 \%$. Nine fungicides significantly increased the weight of marketable tubers (Table 6, homogeneous group $b$ ) which seemingly confirms the necessity to keep foliage in the best health status for the whole season using any effective fungicide in order to reach a profitable potato harvest. The efficacy of fungicides is generally reflected in rAUDPC (Fig. 2). The medium tight negative correlation $(r=-0.626)$ found between rAUDPC and yield of tubers (Table 7) directly supports this result.

In 2015 , the rise of average temperature by $15 \%$ (in August by $24 \%$ ) combined with the extremely low rainfalls (in July 54\% and in September $74 \%$ below the 70 years average) caused the stagnation of the growth of tubers. These conditions reduced the total weight of tubers by $36 \%$ in comparison with the 5 years mean. Considering the marketability of harvested tubers, the loss of the yield in 2015 was 
Table 5 The two-way ANOVA table for characteristics of tubers

\begin{tabular}{|c|c|c|c|c|c|}
\hline Characteristics/factor & Df & Sum sq & Mean sq & $F$-value & $P$-value \\
\hline \multicolumn{6}{|l|}{ Yield of tubers $\left[\mathrm{tha}^{-1}\right]$} \\
\hline Fungicide & 12 & 1582.14 & 131.85 & 5.98 & 0.000 \\
\hline Year & 3 & 2762.87 & 920.96 & 41.76 & 0.000 \\
\hline Fungicide*Year & 36 & 1403.39 & 38.98 & 1.77 & 0.009 \\
\hline Residuals & 156 & 3440.14 & 22.05 & & \\
\hline \multicolumn{6}{|l|}{ Number of tubers } \\
\hline Fungicide & 12 & $33,043.11$ & 2753.59 & 1.50 & 0.129 \\
\hline Year & 3 & $1,296,083.50$ & $432,027.83$ & 235.52 & 0.000 \\
\hline Fungicide*Year & 36 & $45,685.63$ & 1269.05 & 0.69 & 0.902 \\
\hline Residuals & 156 & $286,165.00$ & 1834.39 & & \\
\hline \multicolumn{6}{|c|}{ Number of tubers $<3.5 \mathrm{~cm}$} \\
\hline Fungicide & 12 & 2901.43 & 241.79 & 0.83 & 0.617 \\
\hline Year & 3 & $281,463.48$ & $93,821.16$ & 322.84 & 0.000 \\
\hline Fungicide*Year & 36 & 9231.14 & 256.42 & 0.88 & 0.661 \\
\hline Residuals & 156 & $45,335.00$ & 290.61 & & \\
\hline \multicolumn{6}{|l|}{ Tubers $<3.5 \mathrm{~cm}[\mathrm{~kg}]$} \\
\hline Fungicide & 12 & 1.74 & 0.14 & 0.54 & 0.883 \\
\hline Year & 3 & 306.72 & 102.24 & 384.26 & 0.000 \\
\hline Fungicide*Year & 36 & 9.13 & 0.25 & 0.95 & 0.551 \\
\hline Residuals & 156 & 41.51 & 0.27 & & \\
\hline \multicolumn{6}{|c|}{ Number of tubers $3.5-6.5 \mathrm{~cm}$} \\
\hline Fungicide & 12 & $20,748.33$ & 1729.03 & 1.01 & 0.444 \\
\hline Year & 3 & $893,840.38$ & $297,946.79$ & 173.79 & 0.000 \\
\hline Fungicide*Year & 36 & $60,528.37$ & 1681.34 & 0.98 & 0.508 \\
\hline Residuals & 156 & $267,455.00$ & 1714.46 & & \\
\hline \multicolumn{6}{|l|}{ Tubers $3.5-6.5 \mathrm{~cm}[\mathrm{~kg}]$} \\
\hline Fungicide & 12 & 690.33 & 57.53 & 3.41 & 0.000 \\
\hline Year & 3 & 4479.53 & 1493.18 & 88.45 & 0.000 \\
\hline Fungicide*Year & 36 & 909.27 & 25.26 & 1.50 & 0.049 \\
\hline Residuals & 156 & 2633.45 & 16.88 & & \\
\hline \multicolumn{6}{|c|}{ Number of tubers $>6.5 \mathrm{~cm}$} \\
\hline Fungicide & 12 & 4805.48 & 400.46 & 2.37 & 0.008 \\
\hline Year & 3 & $44,131.31$ & $14,710.44$ & 86.95 & 0.000 \\
\hline Fungicide*Year & 36 & 8742.94 & 242.86 & 1.44 & 0.069 \\
\hline Residuals & 156 & $26,392.50$ & 169.18 & & \\
\hline \multicolumn{6}{|l|}{ Tubers $>6.5 \mathrm{~cm}[\mathrm{~kg}]$} \\
\hline Fungicide & 12 & 403.30 & 33.61 & 2.65 & 0.003 \\
\hline Year & 3 & 2849.58 & 949.86 & 74.83 & 0.000 \\
\hline Fungicide*Year & 36 & 700.50 & 19.46 & 1.53 & 0.040 \\
\hline Residuals & 156 & 1980.25 & 12.69 & & \\
\hline
\end{tabular}




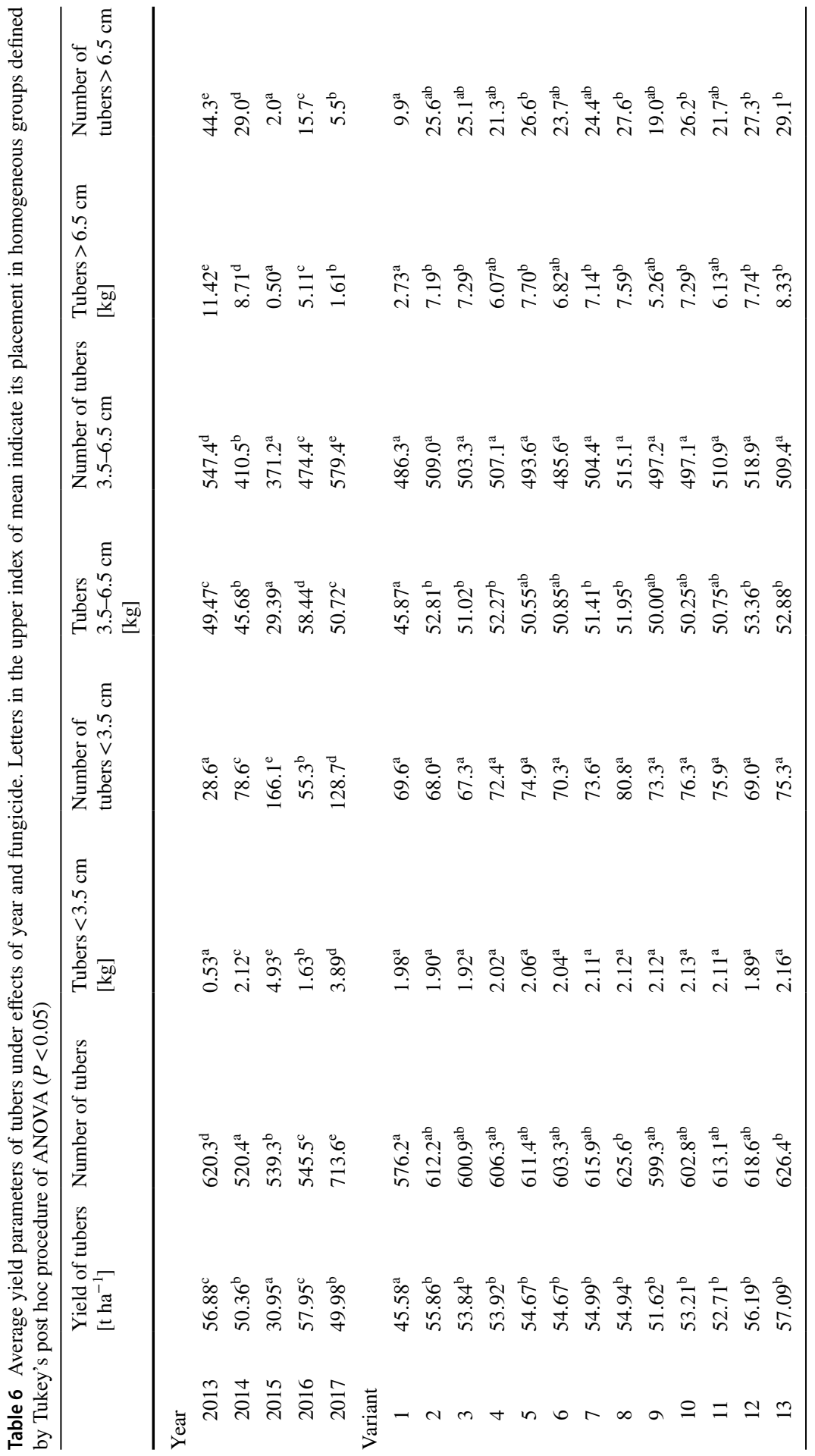




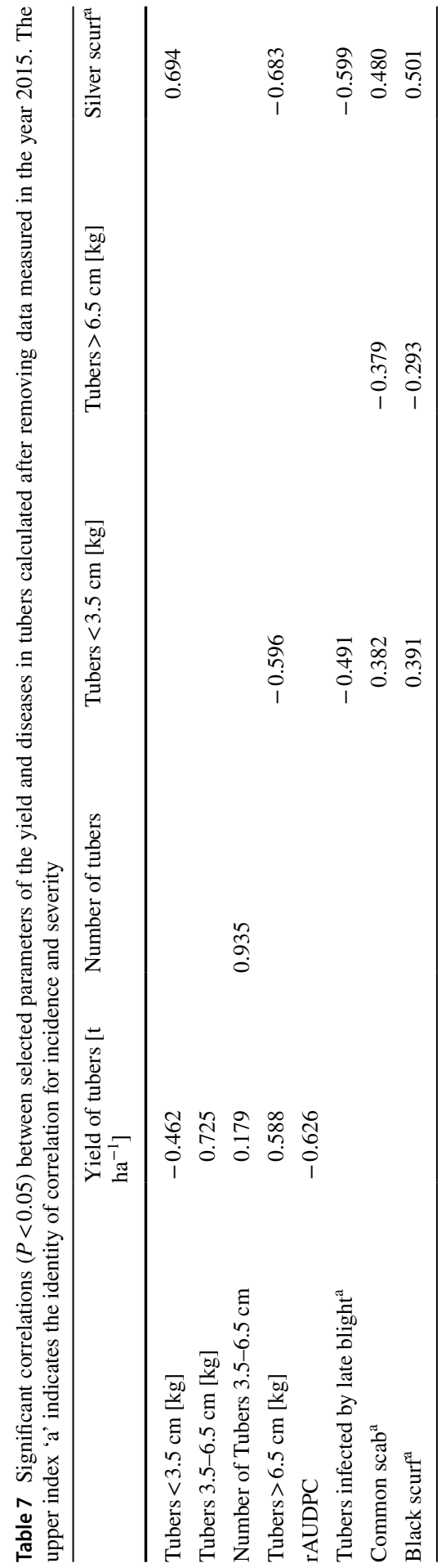


$42 \%$, caused by dryness significantly reducing the quantity of tubers of size above $6.5 \mathrm{~cm}$ in diameter. This reduction correlated with the increasing weight of tubers under $3.5 \mathrm{~cm}$ (Table 7). In relatively normal years (when considering weather conditions), this did not surpass $7 \%$ of total weight of harvested tubers, but in 2015, this value doubled to $14 \%$. The data in Table 5 also show that the category of mediumsized tubers $(3.5-6.5 \mathrm{~cm})$ in normal years represented $80 \%$ of the total harvest, but in such extreme years as 2015, it reached $90 \%$. This is further disclosed by the reduction of quantity of tubers over $6.5 \mathrm{~cm}$, which significantly increases with normal weather conditions. In 2013, this value represented $18 \%$ of the total harvest. These and other correlations are presented in Table 7.

\section{Selected Correlations of Results}

The valuable and statistically significant $(P<0.05)$ correlation coefficients are presented in Table 7 and further commented on in the discussion.

\section{Discussion}

\section{Experimental Conditions}

Repeated foliar application of single commercial fungicides was used in order to verify their efficacy on soil-borne diseases. The need for this experiment was indicated by our previous study (Sedláková et al. 2011), where some trends in efficacy of standard fungicide sequences on the soil-borne diseases were observed. The repeated application of some systemic fungicides or single-site active ingredients goes against the recommended anti-resistance strategy in late blight management. However, this experimental approach was found as the only possible method in identifying concrete effects of tested fungicides under common environmental factors to confirm the previously stated hypothesis.

To keep the homogeneity of experimental conditions, the same locality, soil conditions, fields without previous extreme problems with diseases, and identical potato variety from our previous study were used. Variety Ditta was chosen for good longterm experience and stability in the experimental conditions. Having medium resistance against evaluated diseases, it offered a relatively sensitive scale for evaluation of fluctuations in the progress of soil-borne diseases. The initial contamination of tubers by subject diseases was annually very low; the system of production of certified seed potato efficiently prevents the contamination of tubers by late blight and soil-borne diseases.

Although the experiment was designed with a high degree of simplicity, it was very difficult to identify concrete significant effects of tested fungicides on the soilborne diseases. The heterogeneity of experimental years, which is considered normal in field testing (Lombardo et al. 2013), increased variations in evaluated characteristics. Due to this heterogeneity, however, we were able to detect interactions between fungicide treatments and specific year conditions. The findings are usable 
for predictions of risks of concrete late blight management for progress of soilborne diseases. The long-term effects of fungicides were revealed using ANOVA after removing the anomalous year 2015 and processing data from years as independent repetitions. We used this approach in our previous study (Sedláková et al. 2013) to highlight the significant differences for variables on the neutral background of broader natural variability. The weather extremity in 2015 is considered a possible model demonstrating the impacts of oncoming climatic changes and a warning for standard potato-growing areas. These areas are characterized by more permeable soils and lands localized far from the water resources available for the building of economically effective irrigations required for protecting the yield and quality of tubers.

The progress of late blight in the foliage was initially perceived as a basic precondition of late blight in tubers, especially the date of disease onset and the disease persistence in foliage (Table 2). It was partly confirmed in 2013 when the weather conditions were the best for late blight during the evaluating period (Fig. 1) because of the optimal quantity and distribution of precipitations. Hospers-Brands et al. (2008) also consider the properties of soil or the placement of tubers in the soil as a factor generally aiding the infection in tubers; these factors were however homogeneous in this experiment. The artificial desiccation of the foliage can effectively reduce the quantity of infected tubers (Rasocha et al. 2008). In 2014, the late blight epidemic started 18 days later and the disease period was 37 days shorter in comparison with 2013. Moreover, in 2014, the late blight in foliage was strongly combined with early blight due to the dynamic alternation of dry and wet conditions, which is an essential factor for an early blight outbreaks (Rotem 1994). This resulted in faster natural desiccation of foliage and significantly lower loss of tubers due to late blight. In other years, the leaf diseases developed slowly due to general dryness and late blight on tubers was not high, leading to an insignificant correlation between disease progress in foliage and late blight in tubers.

Considering the soil-borne diseases, we observed their general increasing during the experimental period. This rise was reported previously for silver scurf (Sedláková et al. 2011, 2013) which continued until 2017. The trend can be explained by environmental factors, especially by dry and hot conditions at the end of the vegetative growth. Alongside the initial contamination of seed tubers, they are generally anticipated as the most important factor for all diseases (Rasocha et al. 2008). While the differences in the contamination of seed tubers can be excluded, since the quality of seed tubers did not differ across the experimental years, the weather conditions for the progress of soil-borne diseases in seasons 2015-2017 were fairly optimal. Conversely, the accumulation of late blight was not observed as strongly infected seed tubers are eventually completely destroyed and the progress of disease requires wet and colder weather, which was typical only in seasons 2013-2014.

\section{Effects of Fungicides}

All fungicides used in the experiment significantly protected the foliage (Fig. 2) and yield of tubers (Table 6) in all seasons with occurrence of foliar diseases. 
Considering the general effectiveness of most fungicides against late blight in tubers, Dithane DG Neotec failed in comparison to other fungicides. The fungicide prolonged life of foliage in the late vegetation and supported the production of zoospores entering the soil and tubers. This significantly increased the frequency of injured marketable tubers (above $3.5 \mathrm{~cm}$ in diameter). Considering the mode of action, mancozeb is toxic for germinating spores and does not work curatively (Gullino et al. 2010). It is comparable to copper oxychloride in the more efficient Kuprikol 50. However, the total weight of tubers injured by late blight was very low (probably for their smaller size) at this variant. The proved significant interaction between mancozeb-based fungicides and years with good epidemiological conditions for late blight confirms low efficiency on late blight in tubers. Altima $500 \mathrm{SC}$, containing the active ingredient fluazinam, was generally highly effective despite the rise of resistance of $P$. infestans to fluazinam in Europe, which was recently reported for strain EU33A2 (Schepers et al. 2018). This indicates that during the experimental period, the resistance was not common in the present population of the pathogen. Despite the good efficacy of fluazinam in the experiment, there is still a risk of its failure in future. It should therefore be used less frequently and only in standard sequences of fungicides in order to keep relevant anti-resistance strategy. Schepers et al. (2018) also discussed strengthening the efficacy of fluazinam on the strain EU33A2 with difenoconazole. Difenoconazole was used in this experiment in combination with mandipropamid (Revus Top), adding to the efficacy against complex of foliar disease in comparison to Revus (mandipropamid) in 2014, when the late blight was strongly combined with early blight (Fig. 2). These experiences are very important for the future since oncoming withdrawing of mancozeb will reduce the spectrum of effective fungicides. Consequently, the development of new safer fungicides or effective combinations will be needed.

The repeated foliar applications also have certain effects on soil-borne diseases. Common scab and silver scurf tended to either be improved or worsened by the treatments. The incidence and severity of black scurf were not modified. Especially mancozeb, being relatively effective against black scurf (Atkinson et al. 2011), was not effective against the disease in any tested foliar applications of the five commercial fungicides in which it was an ingredient. The foliar application comes probably too late and the chemical is more dispersed in the soil in comparison with cited seed dressing treatment, which principally reduces the initial growth of the fungus by effective concentration of active ingredient. Good efficacy of preventive treatments of seed tubers exhibiting high severity of the common scab by fluazinam and mancozeb was discussed previously (Wilson et al. 1999). In this experiment, these active ingredients were efficient in foliar applications of Altima $500 \mathrm{SC}$, Acrobat MZ WG and Curzate Gold. This secondary effect can be evaluated as the most beneficial, especially for growers on soils where common scab is a periodically repeating problem. Particularly soil conditions, like the soil composition, content of organic matter supporting antagonistic saprophytes, $\mathrm{pH}$ of soil in the range from 6.5 to 7.0, and dryness of soil in the time of tubers initiation suppressive for the antagonistic bacteria on juvenile tubers (Loria 2001; Rasocha et al. 2008), support the disease. In the fields used in this experiment, the $\mathrm{pH}$ of soil was not a source of variability (as seen in methodology). The variability was more likely an effect of the 
general dryness in 2015 and local dryness in June (seasons 2016 and 2017) which were responsible for an increase of the disease in seasons 2016 and 2017. Besides the dryness, the activity of saprophytic/antagonistic microbiota can also be reduced by toxicity of different fungicides as discussed by Deng et al. (2009) for common overuse of copper-based fungicides. The ANOVA confirmed the interaction of both factors strengthening significantly the incidence of common scab in variants of copper oxychloride (Kuprikol 50), cyazofamid (Ranman Top) and pure mandipropamid (Revus). Conversely, the combination of mandipropamid with difenoconazole (Revus Top) maintained the disease incidence on the level of negative control. So, difenoconazole seems to be not only efficient against the pathogen, but probably also safe for the soil antagonistic microbiota.

Since the effects on soil-borne diseases were observed in both repeated single fungicide application and sequences (Sedláková et al. 2011), maintaining antiresistance strategy for late blight management and carefully reconsidering the use of worsening fungicides into standard application sequences is recommended.

\section{Correlations}

Valuable and interesting correlations between evaluated characteristics (Table 7) were found. The missing correlation between late blight in foliage and tubers can also be explained by differential expression of resistance genes in tubers and foliage (Gao and Bradeen 2016), since the variety Ditta is evaluated as having high resistance in tubers and medium resistance in foliage (European Cultivated Potato Database). The more probable influence was the heterogeneity in experimental years, with 2013 being the only optimal year for the progress of late blight.

The moderately strong negative correlation between yield and rAUDPC was in accordance with results by Sedláková et al. (2011). Interestingly, the late blight in tubers negatively correlated with the number of tubers in the size under $3.5 \mathrm{~cm}$. This seems to be a direct consequence of environmental influences discussed above (4.1).

Unexpectedly, the total number of tubers in the sample does not correlate with the estimated weight of tubers per hectare. This finding is opposed by the conclusion of Cabello et al. (2014) concerning the heritability of these yield characteristics. They found higher environmental variation in the number of tubers than in the weight of tubers. However, in the present study, the relative variation for number of tubers was $15.2 \%$ and $23.2 \%$ for the weight.

A noteworthy correlation was found between late blight and silver scurf, clearly seen in 2013 and 2014 (Table 7). Whether this is due to some antagonism of pathogens or the benefits of environmental factors in two different years, cannot be reliably indicated. Even though Firman and Allen (1995) and Miller et al. (2015) studied Helminthosporium solani comprehensively, a solution for any of these two options has not been found. Correlation of the silver scurf with the black scurf can be considered as indirect evidence of synergism of pathogens similar to other known synergistic interactions of pathogens in different consortia widely analysed by Lamichhane and Venturi (2015), however needing experimental confirmation. Silver scurf incidence/severity also positively correlated with the number of tubers of size under 
$3.5 \mathrm{~cm}$ (and negatively with the number of tubers above $6.5 \mathrm{~cm}$ ). Similar but less tight correlations were also detected for common scab and black scurf. These correlations confirmed results of Carling et al. (1989) who reported quantitative and qualitative loss of tubers due to black scurf. In light of the results, it seems to be highly probable that the pathogen surviving on the seed tubers and co-growing with potato plants stimulates them to initiation of higher number of tubers. This ultimately results in smaller size of tubers, probably as a consequence of competitive distribution of assimilates. However, further research confirming this ecological interaction is needed.

\section{Conclusions}

In the experiment, all potato tuber diseases varied dependently on year. However, the severity/incidence of all monitored potato tuber diseases excluding black scurf has been reduced by specific, below mentioned, fungicide variants helping to improve potatoes in the both quantity and quality.

Generally, all fungicides significantly increased yield of potato in all experimental years. Moreover, fungicides Infinito, Ranman Top and Revus Top significantly reduced the quantity of tubers infected by late blight. Revus Top was also effective against silver scurf.

The fungicides fluazinam (Altima $500 \mathrm{SC}$ ), dimethomorph (Acrobat MZ WG) and cymoxanil (Curzate Gold) reduced symptoms of common scab; they should be preferred in soils and years with high risk of the disease. Conversely, the copper oxychloride (Kuprikol 50), cyazofamid (Ranman Top) and pure mandipropamid (Revus) used in such conditions represent considerable risk of higher disease incidence.

The direct efficacy of these fungicides on microbiota antagonistic to Streptomyces scabiei needs to be experimentally investigated.

Acknowledgements We would like to thank Natalia Wolfe for language corrections.

Author Contribution Conceptualization: P.S., V.S., P.D. and E.H.; methodology: V.S., P.D. and E.H.; investigation: E.H., P.D., P.B. and J.V.; writing—draft: P.S. and V.S.; writing—review and editing: E.H., P.D. and J.V.; funding acquisition: E.H. and V.S.; supervision: V.S. and E.H.

Funding This work was financially supported by the Ministry of Agriculture of the Czech Republic within the framework of The National Agency for Agricultural Research, Project No. QJ1210305, by Institutional aid for the long-term conceptual development of research organizations (MZE-RO1620), and by Internal Grant Agency of Czech University of Life Sciences Prague (SGS SV19-07-21360).

Data Availability The datasets generated and analysed during the current study are available from the corresponding author upon reasonable request.

\section{Declarations}

Ethics Approval Not applicable. 
Consent to Participate Not applicable.

Consent for Publication Not applicable.

Conflict of Interest The authors declare no competing interests.

Open Access This article is licensed under a Creative Commons Attribution 4.0 International License, which permits use, sharing, adaptation, distribution and reproduction in any medium or format, as long as you give appropriate credit to the original author(s) and the source, provide a link to the Creative Commons licence, and indicate if changes were made. The images or other third party material in this article are included in the article's Creative Commons licence, unless indicated otherwise in a credit line to the material. If material is not included in the article's Creative Commons licence and your intended use is not permitted by statutory regulation or exceeds the permitted use, you will need to obtain permission directly from the copyright holder. To view a copy of this licence, visit http://creativecommons.org/licen ses/by/4.0/.

\section{References}

Atkinson D, Thornton MK, Miller JS (2011) Development of Rhizoctonia solani on stems, stolons and tubers of potato II. Efficacy of chemical applications. Am J Potato Res 88:96-103. https://doi.org/ 10.1007/s12230-010-9172-1

Barzman M, Bàrberi P, Birch ANE, Boonekamp P, Dachbrodt-Saaydeh S, Graf B, Hommel B, Jensen JE, Kiss J, Kudsk P, Lamichhane JR, Messéan A, Moonen AC, Ratnadass A, Ricci P, Sarah JL, Sattin M (2015) Eight principles of integrated pest management. Agron Sustain Dev 35:1199-1215. https:// doi.org/10.1007/s13593-015-0327-9

Cabello R, Monneveux P, Bonierbale M, Khan MA (2014) Heritability of yield components under irrigated and drought conditions in andigenum potatoes. Am J Potato Res 91:492-499. https://doi.org/ 10.1007/s12230-014-9379-7

Carling DE, Leiner RH, Westphale PC (1989) Symptoms, signs and yield reduction associated with Rhizoctonia disease of potato induced by tuberborne inoculum of Rhizoctonia solani AG-3. Am Potato J 66:693-701. https://doi.org/10.1007/BF02896825

Deng H, Li X-F, Cheng W-D, Zhu Y-G (2009) Resistance and resilience of Cu-polluted soil after Cu perturbation, tested by a wide range of soil microbial parameters. FEMS Microbiol Ecol 70:293-304. https://doi.org/10.1111/j.1574-6941.2009.00741.x

Errampalli D, Saunders JM, Holley JD (2001) Emergence of silver scurf (Helminthosporium solani) as an economically important disease of potato: review: silver scurf of potato. Plant Pathol 50:141-153. https://doi.org/10.1046/j.1365-3059.2001.00555.x

Ferreira LC, Scavroni J, da Silva JRV, Cataneo AC, Martins D, Boaro CSF (2014) Copper oxychloride fungicide and its effect on growth and oxidative stress of potato plants. Pestic Biochem Phys 112:63-69. https://doi.org/10.1016/j.pestbp.2014.04.010

Finckh MR, Schulte-Geldermann E, Bruns C (2006) Challenges to organic potato farming: disease and nutrient management. Potato Res 49:27-42. https://doi.org/10.1007/s11540-006-9004-3

Firman DM, Allen EJ (1995) Transmission of Helminthosporium solani from potato seed tubers and effects of soil conditions, seed inoculum and seed physiology on silver scurf disease. J Agric Sci 124:219-234. https://doi.org/10.1017/S0021859600072890

Gao L, Bradeen JM (2016) Contrasting potato foliage and tuber defense mechanisms against the late blight pathogen Phytophthora infestans. PLoS ONE 11:e0159969. https://doi.org/10.1371/journal. pone.0159969

Gullino ML, Tinivella F, Garibaldi A, Kemmitt GM, Bacci L, Sheppard B (2010) Mancozeb: past, present, and future. Plant Dis 94:1076-1087. https://doi.org/10.1094/PDIS-94-9-1076

Haas BJ, Kamoun S, Zody MC, Jiang RHY, Handsaker RE, Cano LM, Grabherr M, Kodira CD, Raffaele S, Torto-Alalibo T, Bozkurt TO, Ah-Fong AMV, Alvarado L, Anderson VL, Armstrong MR, Avrova A, Baxter L, Beynon J, Boevink PC, Bollmann SR, Bos JIB, Bulone V, Cai G, Cakir C, Carrington JC, Chawner M, Conti L, Costanzo S, Ewan R, Fahlgren N, Fischbach MA, Fugelstad 
J, Gilroy EM, Gnerre S, Green PJ, Grenville-Briggs LJ, Griffith J, Grünwald NJ, Horn K, Horner NR, Hu CH, Huitema E, Jeong DH, Jones AME, Jones JDG, Jones RW, Karlsson EK, Kunjeti SG, Lamour K, Liu Z, Ma L, MacLean D, Chibucos MC, McDonald H, McWalters J, Meijer HJG, Morgan W, Morris PF, Munro CA, O’Neill K, Ospina-Giraldo M, Pinzón A, Pritchard L, Ramsahoye B, Ren Q, Restrepo S, Roy S, Sadanandom A, Savidor A, Schornack S, Schwartz DC, Schumann UD, Schwessinger B, Seyer L, Sharpe T, Silvar C, Song J, Studholme DJ, Sykes S, Thines M, van de Vondervoort PJI, Phuntumart V, Wawra S, Weide R, Win J, Young C, Zhou S, Fry W, Meyers BC, van West P, Ristaino J, Govers F, Birch PRJ, Whisson SC, Judelson HS, Nusbaum C (2009) Genome sequence and analysis of the Irish potato famine pathogen Phytophthora infestans. Nature 461:393-398. https://doi.org/10.1038/nature08358

Haverkort AJ, Boonekamp PM, Hutten R, Jacobsen E, Lotz LAP, Kessel GJT, Visser RGF, van der Vossen EAG (2008) Societal costs of late blight in potato and prospects of durable resistance through cisgenic modification. Potato Res 51:47-57. https://doi.org/10.1007/s11540-008-9089-y

Hospers-Brands AJTM, Ghorbani R, Bremer E, Bain R, Litterick A, Halder F, Leifert C, Wilcockson SJ (2008) Effects of presprouting, planting date, plant population and configuration on late blight and yield of organic potato crops grown with different cultivars. Potato Res 51:131-150. https://doi.org/ 10.1007/s11540-008-9095-0

Jeger MJ, Viljanen-Rollinson SLH (2001) The use of the area under the disease-progress curve (AUDPC) to assess quantitative disease resistance in crop cultivars. Theor Appl Genet 102:32-40. https://doi. org/10.1007/s001220051615

Lamichhane JR, Venturi V (2015) Synergisms between microbial pathogens in plant disease complexes: a growing trend. Front Plant Sci 06.https://doi.org/10.3389/fpls.2015.00385

Lamichhane JR, Dachbrodt-Saaydeh S, Kudsk P, Messéan A (2016) Toward a reduced reliance on conventional pesticides in European agriculture. Plant Dis 100:10-24. https://doi.org/10.1094/ PDIS-05-15-0574-FE

Lamichhane JR, Osdaghi E, Behlau F, Köhl J, Jones JB, Aubertot JN (2018) Thirteen decades of antimicrobial copper compounds applied in agriculture. A review. Agron Sustain Dev 38:28. https://doi. org/10.1007/s13593-018-0503-9

Lombardo S, Lo Monaco A, Pandino G, Parisi B, Mauromicale G (2013) The phenology, yield and tuber composition of 'early' crop potatoes: a comparison between organic and conventional cultivation systems. Renew Agric Food Syst 28:50-58. https://doi.org/10.1017/S1742170511000640

Loria R (2001) Common Scab. In: Stevenson W, Loria R, Franc GD, Weingartner DP (eds) Compendium of potato diseases. APS Press, St. Paul, pp 14-15

Meyer MC, Bueno CJ, de Souza NL, Yorinori JT (2006) Effect of doses of fungicides and plant resistance activators on the control of Rhizoctonia foliar blight of soybean, and on Rhizoctonia solani AG1-IA in vitro development. Crop Prot 25:848-854. https://doi.org/10.1016/j.cropro.2005.11.008

Miller JS, Hamm PB, Dung JKS, Geary BD, James SR, Johnson DA, Rykbost K (2015) Influence of location, year, potato rotation, and chemical seed treatment on incidence and severity of silver scurf on progeny tubers. Am J Potato Res 92:62-70. https://doi.org/10.1007/s12230-014-9412-X

Rasocha V, Hausvater E, Doležal P (2008) Harmful agents of potato: abionoses, diseases, pests. Potato Research Institute Havlíčkův Brod. Ltd., Czech Republic

Rotem J (1994) The genus Alternaria: biology, epidemiology, and pathogenicity. American Phytopathological Society, USA

Schepers HTAM, Kessel GJT, Lucca F, Förch MG, van den Bosch GBM, Topper CG, Evenhuis A (2018) Reduced efficacy of fluazinam against Phytophthora infestans in the Netherlands. Eur J Plant Pathol 151:947-960. https://doi.org/10.1007/s10658-018-1430-y

Sedláková V, Dejmalová J, Hausvater E, Sedlák P, Doležal P, Mazáková J (2011) Effect of Phytophthora infestans on potato yield in dependence on variety characteristics and fungicide control. Plant Soil Environ 57:486-491. https://doi.org/10.17221/289/2011-PSE

Sedláková V, Dejmalová J, Doležal P, Hausvater E, Sedlák P, Baštová P (2013) Characterization of fortyfour potato varieties for resistance to common scab, black scurf and silver scurf. Crop Prot 48:8287. https://doi.org/10.1016/j.cropro.2013.02.014

Ullrich J, Schrödter H (1966) Das Problem der Vorhersage des Auftretens der Kartoffelkrautfäule (Phytophthora infestans) und die Möglichkeit seiner Lösung durch eine 'Negativ prognose.' Nachrichtenblatt Des Deutschen Pflanzenschutzdienst 18:33-40

Wenzl H, Demel J (1967) Bildskalen für die Beurteilung von Kartoffelschorf und Rhizoctonia - Pocken. Pflanzenarzt 20:77-78 
Wilson CR, Ransom LM, Pemberton BM (1999) The relative importance of seed-borne inoculum to common scab disease of potato and the efficacy of seed tuber and soil treatments for disease control. J Phytopathol 147:13-18. https://doi.org/10.1046/j.1439-0434.1999.147001013.x

Zhu Q, Zhang M, Ma Q (2012) Copper-based foliar fertilizer and controlled release urea improved soil chemical properties, plant growth and yield of tomato. Sci Hortic 143:109-114. https://doi.org/10. 1016/j.scienta.2012.06.008

Publisher's Note Springer Nature remains neutral with regard to jurisdictional claims in published maps and institutional affiliations.

\section{Authors and Affiliations}

\section{Petr Sedlák ${ }^{1}(\mathbb{D})$. Vladimíra Sedláková ${ }^{1} \cdot$ Petr Doležal $^{2}$. Petra Baštová ${ }^{2}$. Jakub Vašek ${ }^{1}$ - Ervín Hausvater ${ }^{2}$}

1 Department of Genetics and Breeding, Faculty of Agrobiology Food and Natural Resources, Czech University of Life Sciences Prague, Kamýcká 129, 16521 Prague 6, Suchdol, Czech Republic

2 Department of Potato Protection, Potato Research Institute Havlíčkův Brod. Ltd., Dobrovského 2366, 58001 Havlíčkův Brod, Czech Republic 